LAW DEPARTMENT

Copenhagen

Business School

Howitzvej 13

DK-2000, Frederiksberg

DENMARK

www.cbs.dk

+4538152612

\title{
COMMENTS ON THE COMMISSION'S GREEN PAPER ON COPYRIGHT IN THE KNOWLEDGE ECONOMY
}

Prepared by the Research Group on

ICT \& Innovation, Law Department,

Copenhagen Business School

Søren Sandfeld Jakobsen, Associate Professor Ruth Nielsen, Professor

Thomas Riis, Professor

Andrej Savin , Associate Professor

Kim Østergaard, Associate Professor 
COMMENTS ON THE COMMISSION'S GREEN PAPER ON COPYRIGHT IN THE KNOWLEDGE ECONOMY ..... 1

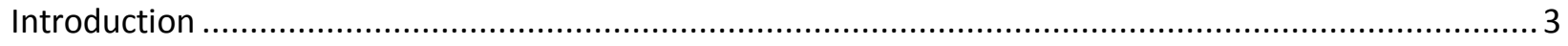

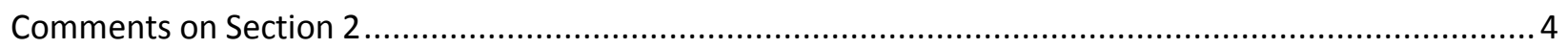

Copyright Exceptions in General and the Three Step Test ........................................................ 4

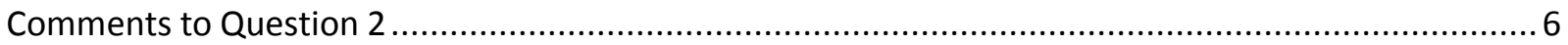

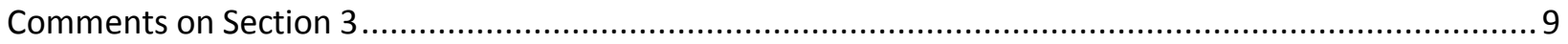

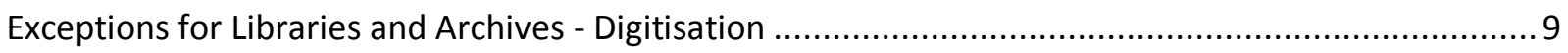

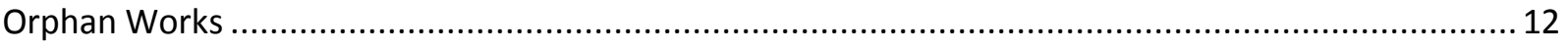

Disability Discrimination and Access to Digital Content ............................................................. 14

Dissemination of Works for Teaching and Research Purposes...................................................... 18

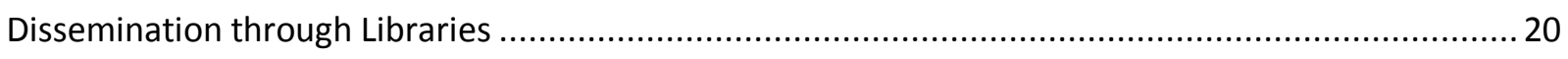

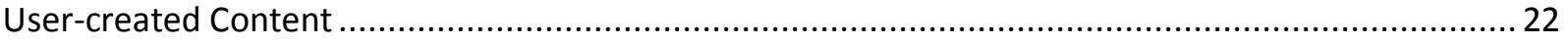

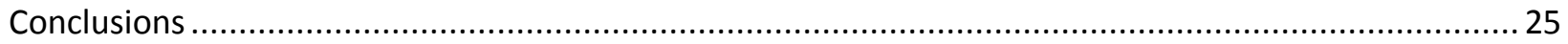




\section{Introduction}

The Commission's Green Paper on Copyright in the Knowledge Economy highlights, above all, the need for a serious research and dialogue on the future of the Information Society Directive. Although the directive had been drafted with the new technology in mind, the developments of the previous decade already show the need for a serious discussion about it. The debate about the issues pointed out in the Green Paper had begun in earnest not only on this side of the Atlantic but on the other, as well as all around the world.

The comments offered on the following pages highlight only the most pressing issues raised by the Green Paper. These relate, in the order in which they have been addressed, to:

- the three step test

- model licenses

- digitization and orphan works

- disability discrimination and access to digital content

- dissemination for teaching and research

- dissemination through libraries

- user created content

Four general conclusions can be drawn from our comments:

$>$ First, the present system of exceptions in Article 5 does not adequately meet the requirements posed by the knowledge economy.

$>$ Second, in addition to doubts concerning how each of the highlighted areas may be accommodated by the exceptions, there are serious issues concerning the three-step-test and its relation to international instruments.

$>$ Third, the international legal rules in this field act not only as a limitation but also provide an opportunity and a framework to answer the posed questions in a globally acceptable manner. These rules need to be understood better and the opportunity they provide exploited. This is particularly true in case of the WIPO Copyright Treaty.

> Fourth, improved understanding is needed of the relationship between EU rules in the areas of, for example, consumer protection, telecoms regulation and electronic commerce and their interface with the present issues. Although often informed by the same or similar policies, visible discrepancies are sometimes apparent between these rules. 


\section{Comments on Section 2}

\section{Copyright Exceptions in General and the Three Step Test}

Copyright has a pronounced international dimension which has resulted in various international legal instruments. In relation to the three-step test, it is stated on p. 5 of the Green Paper that Article 5(5) of the Directive 2001/29 reflects the Community's international obligations in the area of copyright and related rights and Article 9(2) of the Berne Convention and Article 13 of the TRIPS Agreement is mentioned. It is puzzling that the three-step test in Article 10 in the WIPO Copyright Treaty (WCT) is ignored, considering that the European Union is a party to the WCT. ${ }^{1}$

The Berne Convention was adopted in 1886 and subsequently revised and amended several times. The last revision of the Convention took place in 1971. After 1971, substantial revision of the Convention proved impossible because a large number of states were parties to it and any revision requires unanimity between the contracting parties. Nevertheless, the need for modernizing the Convention grew steadily. To meet these needs WIPO presented an independent legal instrument which was referred to as a 'Protocol to the Berne Convention' and that instrument eventually resulted in the WCT in 1996.

In the preamble of the WCT it is stated:

"The Contracting Parties, [Desire] to develop and maintain the protection of the rights of authors in their literary and artistic works in a manner as effective and uniform as possible,

[Recognize] the need to introduce new international rules and clarify the interpretation of certain existing rules in order to provide adequate solutions to the questions raised by new economic, social, cultural and technological developments,

[Recognize] the profound impact of the development and convergence of information and communication technologies on the creation and use of literary and artistic works,

[Emphasize] the outstanding significance of copyright protection as an incentive for literary and artistic creation,

[Recognize] the need to maintain a balance between the rights of authors and the larger public interest, particularly education, research and access to information, as reflected in the Berne Convention"

\footnotetext{
${ }^{1}$ In the Green Paper there is only one reference to the WCT: on p. 8, in footnote 16, the agreed statement concerning Article 1(4) of the WCT is quoted to substantiate the construction of the reproduction right of Directive $2001 / 29$.
} 
In the attempt to map the international obligations in the area of copyright prima facie the WCT and not the Berne Convention is the right reference not only from a strictly legal perspective but also from a practical perspective in the sense that the WCT was adopted in order to 'provide adequate solutions to the questions raised by new economic, social, cultural and technological developments'.

Pursuant to Article 10 of the WCT:

(1) Contracting Parties may, in their national legislation, provide for limitations of or exceptions to the rights granted to authors of literary and artistic works under this Treaty in certain special cases that do not conflict with a normal exploitation of the work and do not unreasonably prejudice the legitimate interests of the author.

(2) Contracting Parties shall, when applying the Berne Convention, confine any limitations of or exceptions to rights provided for therein to certain special cases that do not conflict with a normal exploitation of the work and do not unreasonably prejudice the legitimate interests of the author

In the agreed statements concerning Article 10 of the Treaty it is stated that:

'It is understood that the provisions of Article 10 permit Contracting Parties to carry forward and appropriately extend into the digital environment limitations and exceptions in their national laws which have been considered acceptable under the Berne Convention. Similarly, these provisions should be understood to permit Contracting Parties to devise new exceptions and limitations that are appropriate in the digital network environment. It is also understood that Article 10(2) neither reduces nor extends the scope of applicability of the limitations and exceptions permitted by the Berne Convention.'

The WCT shall not derogate from existing obligations that Contracting Parties have to each other under the Berne Convention ${ }^{2}$ and thus the WCT does not allow usage of copyrightable works that are not permissible under the Berne Convention. However, the WCT adapts the principles of the Berne Convention to the realities of modern life. Hence, Article 10 of the WCT (and the agreed statements) does not support the Green Paper's rigorous interpretation of Articles 9 and 12 of the Berne Convention (Green Paper, p. 20), see also Section 3.4.2 infra. Furthermore, neither Article 9(2) of the Berne Convention, Article 10 of the WCT nor Article 13 of the TRIPS Agreement warrant the pigeon-hole approach of Article 5 of the Directive. Article 5(1)-(4) enumerate exceptions to copyright protection that member states shall or can adopt as part of their national copyright acts. Article 5(1)-(4) provides an exhaustive list of possible exceptions to copyright protection, and consequently, the three step test in Article 5(5) in this way functions as an actual and future absolute lower limit on copyright protection. The three step test of the international (non-EU) legal instruments is a relatively open rule that allows for flexibility in the design of the copyright regime in the future. In Article 5(5) of the Directive it has been replaced by a rule that creates a one-way-only-flexibility in favour of the author. In the light of the expansion of copyright law and of the development of new technologies for the use of copyrightable

\footnotetext{
${ }^{2}$ Cf. Article 1(1) and 1(2) of the WCT and Article 20 of the Berne Convention.
} 
works the need to provide limitations becomes more and more important as a balancing mechanism in a dynamic society.

\section{Recommendation}

We recommend that the list of exceptions in Article 5(1)-(4) of the Directive be made non-exhaustive and that the three step test of Article 5(5) be detached from the list of exceptions and reframed as an independent rule that serves the safeguard of authors' interests but also facilitates a copyright system that allows for future development. Such an amendment would be in conformity with the three step test in the international (non-EU) legal instruments, and in particular with the idea expressed in the agreed statement to Article 10 of the WCT.

\section{Comments to Question 2}

\section{'Should there be encouragement, guidelines or model licenses for contractual arrangements between right holders and users on other aspects not covered by copyright exceptions?'}

The purpose of Directive 2001/29 is i.a. to provide for a high level of protection of intellectual property ${ }^{3}$ which has been implemented by a broad definition of the exclusive rights. In addition, during the last two decades copyright law has expanded in respect of protectable subject matter. Art. 7 of TRIPS Agreement (which the Community and its Member States are bound to respect) comprise the objectives of the Agreement:

'The protection and enforcement of intellectual property rights should contribute to the promotion of technological innovation and to the transfer and dissemination of technology, to the mutual advantage of producers and users of technological knowledge and in a manner conducive to social and economic welfare, and to a balance of rights and obligations.'

As a policy objective, Art. 7 of TRIPS Agreement is a mechanism that balances the interests of creators and the interests of users and it has a strong utilitarian bias. ${ }^{4}$ However, this copyright rationale conforms rather poorly to the existing copyright law because, basically, copyright law is based on the idea that one-size-fits-all. In general copyright terms, a scholarly paper created by a university professor as part of her obligations of employment is treated the same way as a block buster feature film produced by a private film producer and which has required an investment of 10 mio. Euros irrespective that the actual needs between these two categories of works differ substantially and so does the needs of access to the works. $^{5}$

\footnotetext{
${ }^{3}$ Directive 2001/29/EC recital 4, cf. The Green Paper on Copyright in the Knowledge Economy, COM(2008) 466/3, p 4.

${ }^{4}$ The notion of copyright law as a balancing mechanism and its utilitarian core is toned down in the Directive.

${ }^{5}$ See e.g. Michael W. Carroll: 'One for All: The Problem of Uniformity Cost in Intellectual Property Law', American University Law Review 55 (2006): 845-900.
} 
The one-size-fits-all problem can be illustrated in various ways. In several copyright related industries supplying mass market products and services (in particular music and films) the right holders have felt a threat from wide spread unauthorized copying etc. enabled by new technological means (file sharing etc.) As a response the right holders have implemented various systems of technological protective measures and, thus, by private means created a stronger protective regime in order to accommodate the needs of protection. In quite another industry, scientific publishing, subscription prices have increased steadily over the last 30 years from 1975-1995 subscription prices on scientific journals increased $200-300 \%$ in fixed prices. ${ }^{6}$ The increase restricts access to scientific information and the response from the scientific communities is a tendency to publish scientific work in open access journals and institutional repositories. Common for these two examples is that the statutory copyright regime is not optimal. In the former example statutory copyright law create an imbalance that benefits users, in the latter example statutory copyright law create an imbalance that harms users. The response to the imbalances is contracts.

The one-size-fits-all straightjacket (inflexibility) of copyright law is supported by the exhaustive list of exemptions to the exclusive rights in Art. 5 of the Directive. Inflexibility of copyright law is not exclusively due to the Directive being a minimum harmonization one but is integrated in the nature of copyright law in the sense that copyright law consists of formal and abstract legal principles and concepts. E.g. a protectable work needs to be "original" and an original work means that the work constitutes the author's own intellectual creation. "The author's own intellectual creation" is obviously an abstract concept and it is independent of how many resources the author has invested in the creation of the work.

Utilitarian based copyright law requires flexibility in the legal frame work. However, it is not a viable solution to restructure copyright law by adopting detailed rules specific to each category of work and each typical context of exploitation. That would make statutory copyright law even more comprehensible and complex. Preferably, flexibility can be provided by contract. However, in the two examples mentioned above the contractual response has not proven optimal. Technological protective measures have harmed the usability of protected works due to problems of compatibility and the lack of technical standards. Open access publishing is mainly restricted by legal complications, in particular, in respect of the division of rights between the scientist and the scientist's employer (the research institution) (typically, the division of rights differs from one country to another) and the contract practice of the scientific publishers. The case for providing flexibility in copyright law thus should not be aimed at the encouragement of contracts as such but rather at collective agreements and model contracts with the paramount aim of providing uniformity in the legal arrangements within a specific sector.

\footnotetext{
6 "Study on the economic and technical evolution of the scientific publication market in Europe", Brussels 2006, s. 23.
} 
Contractual arrangements between right holders and users can be encourage in various was. Model contracts can be encourage if statute attributes legal value to model contracts that are widely used by using such model contracts as guidelines for the interpretation of statutory rules. Additionally, there may be a case for providing the relevant industries with ready-made model contract such as the EU Open Source License EUPL (European Union Public License) ${ }^{7}$ which has been provided by the European Commission.

Particularly, where there is a high need of access to copyrightable works, and the type of use in question is not covered by copyright exceptions, collective agreements can play a crucial in the copyright regime by adopting provision on extended collective license (such as Art. 3(2) in Council Directive 93/83/EEC on copyright related to satellite broadcasting and cable retransmission). The notion of extended collective licenses originates in Nordic copyright law. For the system to work efficiently, it is a prerequisite that collective organizations representing the right holders exist. On behalf of their members the collective organizations enter into agreements with users of copyright protected works specifying the permitted use of the works and the conditions in this respect. Due to the statutory provisions on the extended collective agreement licenses the effects of the collective agreements is extended to the right holders who are not represented by the collective organizations. Thus, in respect of right holders who are not represented by the collective organizations, extended collective agreement licenses have the same effect as compulsory licenses. In areas where the only practical way of clearing copyrights for the use of protected works is by way of collective licensing, the users cannot be sure that all works and all right holders are covered by the license agreement and thus that all relevant rights have been cleared. Consequently, the users run the risk of copyright infringement. This so-called outsider problem is solved by the extended collective agreement licenses.

Redirecting copyright law towards collective agreements and model contract not only will provide needed flexibility in the copyright regime but, arguably also may address the wide spread problem of non-compliance to copyright rules. Copyright law pervades the daily life of most persons but the significance of copyright law is not reflected in a corresponding respect for copyright law. Among many groups of users behavioural norms suggest that copyright infringement is an acceptable behaviour there can be said to exist a copyright law/norm gap. The legislative response has been to make enforcement of intellectual property rights more efficient, though the effect on behavioural norms is questionable. Users are important stake holders in relation to copyright law and redirecting copyright law towards collective agreements allows the user groups a say or a representation in the copyright regime which contributes to the legitimacy of copyright law and legitimacy is seen as a significant element in the formation of behavioural norms.

\footnotetext{
${ }^{7}$ http://ec.europa.eu/idabc/eupl
} 


\section{Comments on Section 3}

\section{Exceptions for Libraries and Archives - Digitisation}

\section{Policy Background}

Community law presently addresses the problem of digitization in a number of "soft law" instruments. The Commission firstly made digital libraries a priority in the i2010 European Digital Libraries Initiative in $2005 .^{8}$ In this instrument, it set out to make "Europe's cultural and scientific heritage visible and available for present and future use" by digitisation and digital preservation that will "increase accessibility". ${ }^{9}$

In Recommendation on Digitisation ${ }^{10}$ the Commission pointed out that parallel national efforts on digitisation are in progress and that this leads to fragmentation as no clear and comprehensive policies exist in Member States. Importantly, it was further noted that any future efforts on digitisation should happen within respect to the existing EU and international legal framework. "Europe's cultural material should be digitised, made available and preserved in full respect of copyright and related rights."11 In particular this would entail the respect of Directive 2001/29 and the exceptions found therein.

In its response to Recommendation, the Council adopted Conclusions, ${ }^{12}$ agreeing with the Commission's points, inviting the Member States to reinforce and improve their contribution and inviting the Commission to stimulate and co-ordinate work on the European Digital Library" as well as improve policy co-ordination. The Commission and the Council envisage efforts at both EU and national levels.

EU policy documents contemplate models for digitisation but have a relatively vague idea of their legal implications. The High Level Expert Group (HLEG) on Digital Libraries, for instance, envisages the creation of public-private partnerships as models for preservation on a large scale. ${ }^{13}$ The Report expects

\footnotetext{
${ }^{8}$ Communication $\operatorname{COM}(2005) 465$ final.

${ }^{9}$ This is happening at the time when access is given importance internationally and where it is obstructed by the present international copyright treaties. To this effect the World Intellectual Property Organization (WIPO) issued a report on June 29, 2007 recommending using flexible approaches in international IP treaties to increase access in the third world.

${ }^{10}$ Commission Recommendation of 24 August 2006 on the Digitisation and Online Accessibility of Cultural Material and Digital Preservation, 31.8.2006, OJ L 236/28. See also 14 February 2007 Commission Communication on "scientific information in the digital age: access, dissemination and preservation" COM(2007)56

${ }^{11}$ Op.cit. paragraph 10

12 Council Conclusions on the Digitisation and Online Accessibility of Cultural Material, and Digital Preservation, 7.12.2006, OJ C 297/1 and Council Conclusions on scientific information in the digital age: access, dissemination and preservation of 23 November 2007

13 i2010: Final Report on Public Private Partnerships for the Digitisation and Online Accessibility of Europe's Cultural Heritage, May 2008
} 
that existing exceptions in Directive 2001/29 could be used to achieve this aim. ${ }^{14}$ The Final HLEG Report on Digital Preservation ${ }^{15}$ specifically invokes Article 5 of Directive 2001/29.

Two conclusions can be drawn from the preceding:

a) The Commission hopes for a "large-scale digitisation" project encompassing private and public parties from Member States and EU institutions. This effort, as is emphasized in all of the above documents, should eventually lead not only to preservation but also wider access on the Internet. It is clear from the above mentioned documents that the Commission and the Council believe that digitisation ought to go much wider than pure preservation of material. On the contrary, it can probably be said that the accent is on access rather than preservation.

b) No changes to the present legislative framework are envisaged. The digitisation is supposed to take place within the present structure and it ought to take into consideration the principle of subsidiarity and the regulatory margin given to Member States.

At present, large scale digitization even by approved institutions is not covered by Article 5 exceptions. Private entities, such as Google, even if and when they are approved under a national or an EU scheme, are also not covered. In the United States, Google began the process of digitization of both works in the public domain and those under copyright protection some years ago. To this effect, Google entered into agreement with various public libraries, ${ }^{16}$ some of which volunteered their whole collections, others only works under public domain. These libraries include, among others, university libraries of Harvard, Princeton, Stanford, Oxford and Michigan and New York Public Library. A litigation was until recently going on in the United States between McGraw-Hill publishers and Google, where the former claimed that digitization is copyright infringement. The latter defended claiming fair use. ${ }^{17}$ This case has now settled. Other companies use some form of digitization for commercial purposes, another notable example being Amazon. ${ }^{18}$

It is worth noting that "Web-harvesting", which relates to automatic collection of material from the Internet for preservation purposes, is also envisaged in the mentioned documents and likewise almost certainly falls outside the scope of the exceptions altogether.

\section{Existing exceptions}

There are only two potentially relevant exceptions in the present text of Directive 2001/29: the one in Article 5(2)(c) and the one in Article 5(3)(n). The former relates to specific acts of reproduction for non-

\footnotetext{
${ }^{14}$ See p. 19

15 i2010: The Final Report on Digital Preservation, Orphan Works and Out-of-Print Works

${ }^{16}$ Compare public-private model in the EU: i2010: Final Report on Public Private Partnerships for the Digitisation and Online Accessibility of Europe's Cultural Heritage, May 2008

17 McGraw-Hill Cosw. v Google, Inc., 2005 WL 2778878 (S.D.N.Y. Oct 19, 2005) (No. 05 CV 8881)

18 In the United States, the fair use doctrine is used to balance owners' rights and public benefits and such balancing is constitutionally mandated. Fair use can be defined in simplest terms as a reasonable use of a copyrighted work without the owner's permission.
} 
commercial purposes. The latter relates to communication to the public on "dedicated terminals" on the premises. Both exceptions are optional. The list of optional exceptions is exhaustive and subject to three-step-test of Article 5(5). In order for the exception in Article 5(2)(c) to be of relevance for digitisation, it would have to encompass "format shifting", which is the basic idea behind digitisation. It manifestly does not. Article 5(3)(n) is also incompatible with digitisation efforts which, by Commission's own definition, should encompass online access and ought not to be limited to terminals located within library premises.

Member States vary in their approach to "format shifting". The Westkamp report on the implementation of Directive 2001/29/EC ${ }^{19}$ notes that Article 5(2)(c) was implemented in all Member States but that these vary greatly as to the institutions covered and purpose of copying. Overwhelmingly, however, the purpose is archiving or preservation, rather than dissemination. Article $5(3)(n)$ shows similar divergences or has not been implemented at all. It is clear that it is impossible to avoid both disparity between Member States in their efforts to harmonize and the lack of proper legal basis at EU level.

\section{Consistency with International Obligations}

All limitations introduced in Member States are subject to Article 5(5) of the Directive which introduces the Berne "three-step-test". A broad international consensus on limitations of copyright does not exist. The Berne Convention only introduces a set of minimum standards of copyright protection for foreign holders which Member States should respect in their national legislation. The Berne Convention introduces a limited set of exceptions complemented by the "three-step-test". The latter is an internationally recognized standard for creating exceptions to copyright and as such presents a limitation to what the EU and Member States can do without violating their international obligations. It does not appear that a modification of the exceptions to encompass controlled digitisation that fully respected authors' rights would fall foul of the requirements of Article 9 in the Berne Convention.

\section{Recommendation}

It is apparent that no wider access can be achieved under the present set of exceptions. In our opinion, the key economic issue at stake is: does creating a privately owned and operated digital archive of books that enables full access to works in the public domain but only limited access to works protected by copyright, have demonstrable effect on the potential market for these books? In other words, does putting whole libraries online where these contain works under copyright create incentives to purchase these books (in electronic or paper forms) or not. If the answer to that question is in the affirmative, and

\footnotetext{
${ }^{19}$ L. Guibault, G. Westkamp, T. Rieber-Mohn, P.B. Hugenholtz, (et al.) Study on the Implementation and Effect in Member States' Laws of Directive 2001/29/EC on the Harmonisation of Certain Aspects of Copyright and Related Rights in the Information Society, report to the European Commission, DG Internal Market, February 2007. Part II: Country Reports on the Implementation of Directive 2001/29/EC in the Member States, G. Westkamp, Queen Mary Intellectual Property Research Institute, February 2007. Available on http://www.ivir.nl/files/implementation_2001_29 EC/index eng.html
} 
the indications are that it is, then there ought to be no arguments to prevent the modification of Directive 2001/29.

In conclusion, we are of the opinion that the scope of the exception to Article 5(2) needs to be extended to specifically encompass format shifting and scanning of complete collections, under the Communityapproved digitisation efforts as mentioned in the Recommendation and the Opinion. ${ }^{20}$ These efforts need to be undertaken by public libraries but can be entrusted to public-private partnerships or even exclusively to private institutions. At the very least, the Directive ought to accommodate the requirements in Commission's Recommendation and the Council's Conclusions.

\section{Orphan Works}

Orphan works have been the target of European initiatives since mid 2000s. The previously mentioned EU texts on digitisation also cover orphan works.

There are at present three models under which the problem can be solved: extended collective licensing $(E C L)$, centrally granted non-exclusive licensing and limitation on copyright exceptions model. ${ }^{21}$ All three are applied in at least one Member State. Some Member States use none.

In respect of the first, Recital 18 of Directive 2001/29 indicates that Member States are, in principle, free to introduce management-of-rights systems, including ECL. The second model, based on non-exclusive licenses, requires a body that would issue licenses which, in turn, requires guidelines on diligent search. These are already in existence..$^{22}$ In the third model "the user could use the work under an exception to copyrights, there is no administrative body to control if the search for the right holder has been diligent enough and secondly, that the fee would be payable only after the reappearance of the right holder." ${ }^{23}$ This model is not compatible with the exceptions in Directive 2001/29.

No model is currently mandated under EU legislation. It is to be noted that that if different regimes were to be enacted and maintained in Member States, there would be no interoperability across Member States in terms of diligent search criteria. ${ }^{24}$ Furthermore, the existence of a common EU model would be preferable to existence of several national ones and would avoid conflicts at international level.

\footnotetext{
${ }^{20}$ See note 2.

${ }^{21}$ See Vetulani, A, The Problem of Orphan Works in the EU: An Overview of Legislative Solutions and Main Actions in this Field, Report for European Commission (February 2008).

22 See Memorandum of Understanding on Diligent Search Guidelines for Orphan Works at http://www.google.com/url?sa=U\&start=1\&q=http://www.eblida.org/uploads/eblida/2/1213704515.pdf\&usg=AF QjCNHQIE mSXViMkBIZC4-tB5e1kfM-w

${ }^{23}$ Vetualni, p. 14

${ }^{24}$ i2010 Digital Libraries, Copyright Subgroup on Orphan Works and Out-of-Print Work and Key Principles for Rights Clearance Centers
} 
In spite of the fact the majority of EU states do not have laws on orphan works and have not opted for any of the three yet, the creation of a positive climate for the use of orphan works is necessary. In light of the different models, it would be most opportune to:

a) amend Directive 2001/29 to explicitly encompass the third model and

b) work on developments of a separate statutory instrument for orphan works ${ }^{25}$

${ }^{25}$ Which is the solutions the United States have opted for in the draft "Orphan Works Act 2006", HR 5439, 109 Cong., 2 d sess. (2006) 


\section{Disability Discrimination and Access to Digital Content}

\section{Introduction}

The Green Paper mentions that the EU is a party to the TRIPS Agreement. This agreement is, however, not the only international convention of relevance to the issues discussed in the Green Paper. In 2007, the EU signed the UN Convention on the Rights of Persons with Disabilities. ${ }^{26}$ Article $30(3)$ of this Convention provides:

3. States Parties shall take all appropriate steps, in accordance with international law, to ensure that laws protecting intellectual property rights do not constitute an unreasonable or discriminatory barrier to access by persons with disabilities to cultural materials.

On the second of July 2008, the Commission proposed ${ }^{27}$ a Council Directive on implementing the principle of equal treatment between persons irrespective of religion or belief, disability, age or sexual orientation outside of the labour market, in the following called the horizontal Directive. The proposed Directive which inter alia covers non-discriminatory access to and supply of goods and services builds upon previous directives ${ }^{28}$ which prohibit discrimination on grounds of racial or ethnic origin, age, disability, sexual orientation, religion or belief and sex.

The UN Convention on the Rights of Persons with Disabilities and the proposed horizontal Directive are not mentioned in the Green Paper on Copyright in the Knowledge Economy. That is in our view a shortcoming. There is a need for more reflection on the interaction of the horizontal prohibition of discrimination on grounds of disability and copyright in the knowledge economy.

\section{General questions}

On its homepage on disability, ${ }^{29}$ the Commission declares that:

Disability is a rights issue and not a matter of discretion. This approach is also at the core of the UN Convention on the Rights of People with Disabilities, to which the European Community is a signatory.

The Copyright Directive ${ }^{30}$ protects only the economic rights (not the droit moral of the rightholder). The economic rights are divided into a reproduction right (Article 2), a right of communication to the public of works and a right of making available to the public other subject-matter (Article 3) and a distribution

\footnotetext{
${ }^{26}$ Available at http://www.un.org/disabilities/.

${ }^{27} \operatorname{COM}(2008) 426$.

${ }^{28}$ Directive 2000/43/EC on equal treatment between persons irrespective of racial or ethnic origin, Directive 2000/78/EC establishing a general framework for equal treatment in employment and occupation and Directive 2004/113/EC on equal treatment between men and women in the access to and supply of goods and services.

${ }^{29} \mathrm{http}: / /$ ec.europa.eu/social/main.jsp?catld=429\&langld=en.

${ }^{30} 2001 / 29 /$ EC.
} 
right (Article 4). The rightholder's rights include both commercial and non-commercial use of his or her work. The rights of rightholders under Articles 2, 3 and 4 of the Copyright Directive must be exercised in a way that respects bans on discrimination, i.e. currently the bans on sex discrimination and race discrimination in directives 2004/113 EC and 2000/43/EC. When/if the proposal for a horizontal antidiscrimination directive prohibiting discrimination outside the labour market on grounds of religion, age, sexual orientation and disability is adopted, the rights in the copyright directive will also be limited by a ban on discrimination on those grounds. The scope of the proposed horizontal anti-discrimination directive is, however, limited. Under Article 3 (d) the prohibition of discrimination shall apply to all persons, as regards both the public and private sectors, including public bodies, in relation to access to and supply of goods and other services which are available to the public. This subparagraph shall, however, apply to individuals only insofar as they are performing a professional or commercial activity.

There is a need for further reflection on the interaction of the various international and EU law pieces of legislation in this area including the balancing of economic and social rights in the knowledge economy. There is also need for clarification of the basic concepts (disability, discrimination, reasonable accommodation, universal design, etc.). There is no definition of disability neither in the UN convention nor in the draft horizontal Directive. It is usually estimated that there are around 50 million persons with disabilities in the EU. The preamble to the UN Convention contains the following recital:

(e) Recognizing that disability is an evolving concept and that disability results from the interaction between persons with impairments and attitudinal and environmental barriers that hinders their full and effective participation in society on an equal basis with others,

According to Article 2 of the Convention, for the purposes of the UN Convention on the Rights of Persons with Disabilities:

"Communication" includes languages, display of text, Braille, tactile communication, large print, accessible multimedia as well as written, audio, plain-language, human-reader and augmentative and alternative modes, means and formats of communication, including accessible information and communication technology;

"Language" includes spoken and signed languages and other forms of non spoken languages;

"Discrimination on the basis of disability" means any distinction, exclusion or restriction on the basis of disability which has the purpose or effect of impairing or nullifying the recognition, enjoyment or exercise, on an equal basis with others, of all human rights and fundamental freedoms in the political, economic, social, cultural, civil or any other field. It includes all forms of discrimination, including denial of reasonable accommodation (emphasis added);

"Reasonable accommodation" means necessary and appropriate modification and adjustments not imposing a disproportionate or undue burden, where needed in a 
particular case, to ensure to persons with disabilities the enjoyment or exercise on an equal basis with others of all human rights and fundamental freedoms;

"Universal design" means the design of products, environments, programmes and services to be usable by all people, to the greatest extent possible, without the need for adaptation or specialized design. "Universal design" shall not exclude assistive devices for particular groups of persons with disabilities where this is needed

Both the UN Convention on the Rights of Persons with Disabilities and the proposed horizontal Directive define the denial by a service provider of reasonable accommodation for people with disabilities as discrimination. There is need for a further clarification of what the duty of reasonable accommodation consists in and to what extent there is or should be a duty to use universal design.

\section{The Commission's specific questions relating to disability}

In the Copyright Directive and the Green Paper, disability is only dealt with in the context of Article 5 of the Copyright Directive which opens a number of options for Member States to provide for exceptions and limitations. That will be a too narrow view when (and if) the EU adopts a ban on disability discrimination in the access to and supply of goods and services including a requirement of reasonable accommodation and use of universal design and thereby limits the rights under Articles 2, 3 and 4 of the Copyright Directive. It is already as the law stands at present too narrow if the EU wants to live up to the standard required by the UN Convention on the Rights of Persons with Disabilities to which the EU as mentioned is a signatory.

Under the three-step test in Article 5(5) of Directive 2001/29 exceptions and limitations provided for in Article 5, paragraphs 1, 2, 3 and 4 shall only be applied in certain special cases which do not conflict with a normal exploitation of the work or other subject-matter and do not unreasonably prejudice the legitimate interests of the rightholder. This three-step test reflects the trade oriented aspects of the EU's international obligations in the area of copyright and related rights. The three-step test is set out in similar terms in Article 9(2) of the Berne Convention and in Article 13 of the Agreement on TradeRelated Aspects of Intellectual Property Rights ("the TRIPS Agreement"), to which the Community is a party. In the Green Paper on Copyright in the Knowledge Economy ${ }^{31}$ it is stated that this three-step test has become a benchmark for all copyright limitations (emphasis added). That is somewhat exaggerated. It does not apply to the copyright limitations following from discrimination bans. As set out above in section 2, it is not sufficient to look at the interaction of copyright and discrimination law as a problem of providing suitable Article 5 exceptions from the copyrights of the rightholders for users with disabilities.

We have no comments on the whether people with a disability should enter into licensing schemes with the publishers in order to increase their access to works. In our view there should not be mandatory provisions that works are made available to people with a disability in a particular format or that people

${ }^{31} \operatorname{COM}(2008) 466$ of 16 July 2008 p. 5. 
with a disability should not be required to pay remuneration for using a work in order to convert it into an accessible format. The general requirement of reasonable accommodation will probably suffice. The above general prohibition against disability discrimination applies to all kinds of disabilities, not particularly to visual and hearing disabilities. The general prohibition against disability discrimination applies to access to and supply of goods and services irrespective of whether or not they come within the ambit of particular directives such as the Copyright Directive or the Database Directive. ${ }^{32}$

32 96/9/EC. 


\section{Dissemination of Works for Teaching and Research Purposes}

Section 3.3 of the Green Paper deals with dissemination of works for teaching and research purposes. This section is aimed at the exception in Art. 5(3)(a) of Directive 2001/29. Another issue related to dissemination of works for teaching and research purposes of great importance in the Knowledge Economy is the legal framework for publication of scientific works; in particular open access publication.

The Council of the European Union Presidency concluded at the Council meeting in March 2008 that

"Member States and the EU must remove barriers to the free movement of knowledge by creating a "fifth freedom" based on: ... [among other things] open access to knowledge and open innovation"133

It has already been mentioned that open access publishing is restricted by legal complications, in particular, in respect of the division of rights between the scientist and the scientist's employer and the contract practice of the scientific publishers. Directive 2001/29 does not address the issues of open access and does not facilitate open access. The primary problem in this respect relates to the political controversial issue of ownership of rights which has not been harmonized in the EU. Basically, it is a question on who owns the copyright to the work and thus is entitled to decide the means of publication. Public funded research institutions (primarily universities) have a strong interest in making the scientific works of its faculty accessible in institutional repositories but can only do that if they own rights to the work. If the individual scientist owns the copyright and has assigned the copyright to a scientific publisher on an exclusive basis accessibility in an institutional repository is precluded. Among the EU member states large differences exist in respect of the division of copyrights in employment. In Great Britain the Work-Made-for-Hire doctrine applies which in general terms means that the copyright is transferred to the employer. ${ }^{34}$ It is the main rule in continental European jurisdictions that the copyright remains at the employee and only to a limited (and varying) extent is transferred to the employer under specific circumstances. The different national rules on the transfer of copyright in employment complicates open access publishing and the complications are magnified by the fact that research works often are created by several scientists from several research institutions from several countries. This situation suggests a harmonized rule on the ownership of copyright to (public funded) scientific works created in employment as a rule on presumption of ownership (similar to Art. 14, stk. 3 of the Council

\footnotetext{
${ }^{33}$ See also 'The Communication from the Commission to the European Parliament, the Council and the European Economic and Social Committee on Scientific Information in the Digital Age: Access, Dissemination and Preservation', $\operatorname{COM(2007)} 56$ final: 'Initiatives leading to wider access to and dissemination of scientific information are necessary, especially with regard to journal articles and research data produced on the basis of public funding.'

${ }^{34}$ Cf. Copyright, Designs and Patents Act 1988, Sect. 11(2): 'Where a literary, dramatic, musical or artistic work is made by an employee in the course of his employment, his employer is the first owner of any copyright in the work subject to any agreement to the contrary".
} 
Regulation (EC) No 6/2002 of 12 December 2001 on Community designs and Art. 2, stk. 3 of the Council Directive of 14 May 1991 on the legal protection of computer programs (91/250/EEC)).

Apart from the issue on ownership of copyright to scientific works created in employment there is a strong case for supporting the clear policy objective on open access publishing by standardize the agreements on publishing scientific works by use of model contracts or by other contractual means as mentioned above under "Section 2, Question 2". 


\section{Dissemination through Libraries}

The exception in Art. 5(3)(n) in the Copyright Directive gives public libraries and other public-interest establishments a distinct right to distribute certain copyright protected material on the premises only for private study. Whereas publishers normally charge for such a service, this is provided without a fee. The access to the above mentioned material can be considered a "public good" which the public will pursue depending on the transaction-costs (search costs) involved with the process. The exception for public libraries and other public interest establishments on one hand and the publishers on the other hand can be considered as two different channels of distribution, where the first one gives the public free access, since it is subsidized by a member state, while the latter in the long run has to make a profit to stay in the business. Thus, the two parties compete on different premises. If extending this model to providing material on users' home computers becomes the way to distribute copyright protected material over time, the rightholders' incentive to do research and publish might, ceteris paribus, come into question. ${ }^{35}$ The public, however, will still have incentive to enter into any subscription agreement with a publisher as long as transaction costs are higher than the subscription fee.

\section{The "public good" problem}

The economic problem in all cases of harmful effects is how to maximise the value of production. ${ }^{36}$ Or, in other words, how should the law help create a Kaldor-Hicks efficient situation? The value of the access to knowledge is quite difficult to estimate. However, there is hardly any doubt that the availability of digitised works in public libraries is beneficial in many ways. First of all the access to knowledge is free of charge for the public. ${ }^{37}$ As there is a free access to knowledge there are no restrictions to the numbers of journals, articles etc. a person can look into. If the public instead had to pay for the knowledge each person would have to be careful in the process of obtaining the right knowledge, since each person has limited financial resources to obtain the right information. Researchers normally get easy and convenient access to knowledge, which they formerly had to obtain in a hardcopy format. The availability of digitised works reduces the search costs for each individual depending on their ability to command the different search engines in the public libraries.

In summary, from an economic point of view, the availability of digitised works through the public libraries creates significant benefits to the public. However, it is very difficult to estimate the value of this economic output. In order to justify the current state of law the value of the economic output must be compared to the actual and potential harmful effects brought upon the publishers. Thus, the economic output of the free access to knowledge must exceed the value of the harmful effects caused

\footnotetext{
${ }^{35}$ A rightholder can have other incentives to publish besides the pure economic benefit derived from the copyright protected work, such as reputation.

${ }^{36}$ See especially R.H. Coase, The Problem of Social Costs, The Journal of Law \& Economics, Vol. III, 1960, p. 207 250.

${ }^{37}$ It must be taken into consideration that the running of a public library is based on governmental support, and thus paid by the tax-payers as a whole.
} 
to the publishers. Although there is evidence that the change in distribution of music from the "traditional" CD to digital distribution has caused harmful effects to the record industry ${ }^{38}$ it is less clear that the market for digitised works, if made available through home computers in addition to dedicated terminals, would evolve in the same manner. It is also not very likely that the economic loss equals the amount derived from the sales of a subscription fee. This will of course, among other things, depend upon the knowledge available through the publisher and the price of the subscription fee. In other words, some people will not have signed up for a subscription, even though the price asked might have been quite low.

From the point of view of the publisher the free distribution of knowledge through the public libraries can be considered as an economic threat, unless the publishers are able to establish a "business model" which is capable of handling the challenges of the free distribution of knowledge through the public libraries. The recent Google settlement might be an indication that such arrangements are possible.

With respect to scientific articles and books it is probably crucial that the publisher adds a value, which the researcher is not capable of achieving on his own. That might for instance be in the high ranking, which is of great importance to the researcher, by which it becomes crucial to publish an article through a journal to which the publisher has the rights. Other aspects might be whether the publisher offers the distribution in hard-copy as well as an e-book, which eventually might be distributed as a whole or in parts depending on the market.

Another key question relates to the income the publishers achieve through the licensing agreements made with the public libraries. Does the profit from such activity equal the profit derived from the publisher's own online access to their catalogue? This would of course imply that the publishers would have to differentiate among its online customers, which some of them already do.

\section{Conclusion}

Some of the crucial factors which have to be taken into consideration are outlined above. Whether the current exception in Art. 5 (3) (n) remain unchanged or not, however, depends on further in depth research, including a study on the potential effects on both the public and the publishers.

\footnotetext{
${ }^{38}$ The physical "single" as a format is expected to disappear within the foreseeable future in the U.S. The drop in sales has been less dramatic in Europe, but still substantial.
} 


\section{User-created Content}

\section{Introductory remarks}

The purpose of the Green Paper is to foster a debate on how knowledge and innovation can best be disseminated in the online environment. Indeed, the free movement of knowledge and innovation, the so called "Fifth Freedom", ${ }^{39}$ is a cornerstone in the efforts to creating a true, single market within EU. The free movement of knowledge and innovation must, on the other hand, be build on a high level of copyright protection as this is crucial for the development and maintenance of intellectual creativity at all.

Weighing free dissemination of knowledge and innovative works against copyright protection is - and has always been - a fundamental concern in copyright law, and one which has been fuelled by the emergence of the Internet. The worldwide nature of the Internet and the digital technology, which makes it easy for anyone to copy, modify, rearrange and make public available most kinds of artistic and literal works, represents a genuine and very real threat to authors and other right holders' interests.

This threat to copyright protection is further increased by the advent of user-created content and the whole notion of "Web 2.0", i.e. the use of World Wide Web technology and Web design to enhance creativity, information sharing, collaboration and functionality of the Web. As mentioned in the Green Paper user-generated content services - or "Web 2.0 applications" - cover, inter alia, weblogs (blogs), podcasts, wikis and video sharing. All services which (very easily) can be used for creating, uploading and sharing all kinds of content, whether it be text, video or pictures, music etc. US based services such as Facebook, MySpace, YouTube etc. are user-generated content services known to almost anyone around the world, even though most of them are not more than 3-5 years old.

As opposed to "the old media" - newspapers, magazines, radio and television etc. - who exercise editorial control over the content they publish/transmit, and where the content is mostly produced by employed journalists, user-generated content services are normally characterised by the fact that the users themselves can upload content to the web service, without any prior editorial control from the provider of the service. In other words can anyone be a "journalist". Further, as it is quite simple to establish and launch a blog or another kind of user-generated service, anyone can in principle also form their own media platform. This new reality has the potential to revolutionize the media business and boost knowledge sharing, creativity, innovation, media pluralism and freedom of speech in society.

Hence, there appears to be strong reasons for taking a critical view on any legal rule or framework that may constitute a barrier for gaining the full benefit of user-generated content services in the knowledge economy. That includes copyright law.

${ }^{39}$ Re Com 2007724 final of 20.11.2007: A single market for 21st century Europe. 


\section{Comments on the views represented in the Green Paper}

Under the Directive $2001 / 29^{40}$ the right holder(s) have the exclusive right to make reproductions of protected works by any means and in any form, as well as the exclusive right of communication and making available to the public of the works, re art. 2 and 3. As stated in the Green Paper the Directive does not currently contain an exception which would allow the use of existing copyright protected content for creating new or derivative works. The question is, of course, whether such an exception should be adopted.

The Green Paper seems to assume, however, that an exception of this kind will have to have a narrow scope in order not to contravene with the Berne Convention. ${ }^{41}$ According to the Berne Convention art. 12 authors of literary or artistic works shall enjoy the exclusive right of authorising adaptations, arrangements and other alterations of their works. An exception to this right would have to pass the three-step test pursuant to art. 9, according to which exceptions can only be made in certain special cases, provided that it does not conflict with a normal exploitation of the work and does not unreasonably prejudice the legitimate interests of the author.

Referring to these provisions the Green Paper states that an exception "would have to be more precise and refer to a specific policy justification or types of justified uses. It would also have to be limited to short takings (short passages, excluding particularly distinctive takings), therefore not infringing the right of adaptation."

The view that an exception for creating new or derivative works (for e.g. user-generated content services on the Internet) would have to be limited to short takings, excluding particularly distinctive takings, in order not to infringe the rights under the Berne Convention, seems questionable. No case law or legal studies supporting this view are quoted in the Green Paper, and the interpretation of the threestep test and the possible exceptions that can be made from the author's exclusive rights under the Berne Convention are in whole not clear and seem to vary among the parties to the Convention.

Hence, the limitations that follow from the Berne Convention in relation to adopting an exception under EU law for the creation of new or derivative works should be subject to more thorough studies.

The Green Paper also discusses the possible application of some of the current exceptions in the Directive with respect to free uses of works. Art. 5(3)(d) allows quotations "for purposes such as criticism or review". The fact that criticism and review are only examples of possible justifications for quotations implies that art. 5(3)(d) can be given a broad scope, although the quotation must be limited to "the extent required by the specific purpose", and in accordance with "fair practice". Further, some flexibility seems to follow from the exception in art. $5(3)(\mathrm{k})$ which exempts uses "for the purposes of caricature, parody or pastiche".

\footnotetext{
${ }^{40}$ Directive 2001/29/EC.

${ }^{41}$ Berne Convention of 1886 for the Protection of Literary and Artistic Works.
} 
It is correct that both exceptions seem to provide some measure of flexibility in relation to free uses of works. However, it is highly uncertain as to whether the exceptions provide enough flexibility to achieve the full benefit of creative and innovative user-generated content. Both the exception regarding quotation and the exception regarding caricature etc. seem rather narrow and aimed at rather specific kinds of content. Moreover, both exceptions lack clear definitions and scope. Hence, there is a risk that the application of these exceptions will create more problems than they solve.

\section{Answers to the questions posed in the Green Paper}

Re question 1: There should be more precise rules regarding what acts end users can or cannot do when making use of materials protected by copyright.

Re question 2: An exception for user-created content should be introduced into the Directive. The Berne Convention's possible limitations to the extent and scope of such rule should be reviewed more thoroughly.

\section{Other legal barriers}

It should be noted that copyright law is not the only legal framework which may constitute a barrier for obtaining the full benefit of user-generated content services. Also the rules on intermediary liability in the E-Commerce Directive ${ }^{42}$ can constitute a barrier, as there seem to be some uncertainty with respect to the applicability of these rules on providers of services that allow user-generated content to be uploaded. In addition, the application of the directives on personal data ${ }^{43}$ on services offering usergenerated content seem to be uncertain in different respects. Hence, it might be appropriate to include these - and other relevant - directives in a broad review of the barriers under EU law for a successful application of creative and innovative content disseminated online.

\footnotetext{
${ }^{42}$ Directive $2000 / 31 /$ EC.

${ }^{43}$ Directive 95/46/EC and 2002/58/EC.
} 


\section{Conclusions}

In March 2008 the European Council famously announced:

"Member States and the EU must remove barriers to the free movement of knowledge by creating a 'fifth freedom'.

Whereas it may be true that this statement implies or demands no immediate changes in the Treaty, it is not less true that no freedom of information can be achieved without serious rethinking of the present legal framework in the EU as it applies to knowledge economy. This is apparent to the Commission itself as it begins, through the present and other initiatives, to think about possible changes to the legal framework.

It is also increasingly obvious that the ultimate declared aim of the legislation in this field (dissemination of knowledge in the online environment) cannot be reached without profound and potentially courageous intervention. In this, however, the EU is not unique. Some outlines of what these changes might imply are given in the international documents (notably the WCT treaty) but also in national and EU initiatives.

Any changes in this field, however, are not independent from the needs of those to whom they are addressed. The need for proper empirical study in the area of knowledge economy, therefore, cannot be emphasized highly enough. A number of dilemmas, and notably those relating to how the public and the incumbent knowledge industry might be affected by changes in the exceptions system, could be resolved by having proper data.

The comments given in the previous pages highlight one thing above all: the need for further study. Better understanding of the changes in the modern economy that have an impact on the online environment, the implications of any intervention and the international dimension of the problem are all necessary for achieving this desired aim. 